\title{
TEACHING WITH STORIES: ENGAGING STUDENTS IN CRITICAL SELF-REFLECTION ABOUT POLICING AND IN/JUSTICE ${ }^{\circ}$
}

\author{
Jennifer L. Ferguson \\ Michael Musheno \\ Arizona State University
}

\begin{abstract}
In a course entitled "Policing and In/Justice" we elicited stories about policecitizen encounters through a narrative-based writing assignment. The assignment required students to identify competing perspectives of the story's events. Building on these perspectives, students engaged in assessment and evaluation of police decision-making. We suggest similar assignments may be relevant to courses with students anticipating or engaged in policing careers. The growing emphasis on community policing raises expectations that officers be creative problem-solvers, not just law enforcers. In addition to establishing the significance of the assignment, we explain how we accomplished it, and report on what students gained from it.
\end{abstract}

Maria (a Latina citizen): Listen, I told you the only reason that officer pulled my car over was because I was a brown woman in an old car!! If I was a white woman in a new car he would have never, never stopped me!!

Doug (an Anglo police officer): Let's get something straight! White women in new cars do not create crime! It's you Mexicans driving your old tan Monte Carlos that create crime! That's why we did this . . .sweep. . . in the first place! You think that the white people enjoy being scared every time they have to go into town and deal with you people. Hell, I don't even like it, and it's my job!

Maria and Doug are fictional characters in a story written by a junior in a course on "Policing and In/Justice" that addresses the public controversy surrounding a municipal police department's "sweeps" or "roundups", intended officially to identify and deport illegal immigrants. The accounts of Maria and Doug are part of a student's response to a narrative-

"We would like to thank our students in the course "Policing and In/Justice" at Arizona State University during the Fall 1997 and Spring 1998 semesters. This paper is the result of their willingness to take the writing assignment seriously, to engage in reflection about policecitizen encounters and to allow us to share their insights. Also, we thank the anonymous reviewers for comments on an earlier draft of this manuscript. The Story of Francisco was collected as part of a narrative-based research project supported by a National Science Foundation Grant, Law and Social Sciences Program, grant number SBR-9511169. 
based writing assignment designed to strengthen perspective-taking about police-citizen relations in contemporary urban America. Specifically, the assignment invites students to revisit their felt beliefs about policing through storytelling and to make reasoned judgements about police decision-making based on the writing and analysis of narrative.

The assignment asks students to work with stories, their own or those reported in the media, acquire competing perspectives of action-events embedded in the stories, put themselves in the shoes of the characters espousing each perspective, devise evaluative questions that uncover the policing issue at stake, and use norms and analytical constructs learned throughout the semester to lay claim to reasoned judgements about police decisionmaking in contemporary urban society. This manuscript provides an overview of the narrative-based assignment, how we achieved it, and the pedagogy that undergirds it. It also reports on how students responded to the assignment in the first year of its application. We conclude with our ideas about how to further investigate the effectiveness of such an assignment.

\section{WHY STORIES-WHY FOCUS ON JUDGEMENTS?}

Policing is about making judgements (Herbert 1997; Lipsky 1980; Musheno 1986); and urban citizens judge the state substantially on what they think of the judgements made by street-level, public workers (Tyler 1990; Tyler et al. 1997). Upper division courses in justice studies (and criminal justice) programs are populated by citizens interested in learning about the judgements of state agents, particularly the police, and by citizens with aspirations to be effective state agents.

Too often, the temptation for instructors of such classes is to tell students what judgements they should make about the police and/or how their judgements as practicing (aspiring) state agents should be made. Such a strategy fails to recognize the importance of "discursive democracy" or creating the space and tools for citizens to reason about the right thing to do (Dryzek 1990; Schneider and Ingram 1997). Our course on "Policing and In/justice" begins with a story - The Story of Francisco (see Appendix) - and invites students to talk about whether the key police character in the story did the right thing and why. The Story of Francisco is, in part, about police exceptionalism in which coercive powers are withheld to the benefit of a citizen occupying marginal cultural space. It is intended to invoke discussion about what normative orderings (Herbert 1997) guide the officer in his or her decision, to unsettle the notion that the police are guided only by law, and to invoke in students their thoughts about race and ethnicity (Giroux 1996; Gooding-Williams 1993) as they weigh their judgements about whether the officer did the right thing in letting Francisco go.

The Story of Francisco is a narrative of a line police officer who told his story to the second author as part of an ongoing study which draws upon 
storytelling as a way to uncover the norms that street-level, public employees invoke to make judgements and to explore the role that identity plays in invoking particular norms at particular moments of citizen-state agent interactions ( Musheno 1986; Oberweis and Musheno 1999; Shearing and Ericson 1991). Stories are essential cultural artifacts: they are mediums through which we interpret our world and give meaning to events (Polkinghorne 1988). Stories are also essential to our cognitive abilities, with some research suggesting that human memory and knowledge are, at least in part, story-based (Martin 1982; Shank 1990). When we experience an event, we think of it in story form so as to be better able to compare it to our existing log of experiences, also in story form, and to file it away in our memories for future reference. Stories, therefore, can reveal, not only to ourselves, but to others the meaning or meanings that we give to specific events.

Eliciting stories from people is a means by which we can interpret their understandings or perspectives on particular issues, including their perspectives on social in/justice (Ewick and Silbey 1998; Hummel 1990, 1991; Pettigrew 1979). A concern in all inquiry about norms and judgements is respondent bias towards giving the official or socially acceptable views, not those that actually guide choices and actions (Argyris and Schon 1978). Story analysis does not eliminate this problem, but it does minimize it relative to other procedures for eliciting peoples' judgements. Although collected overtly, stories are more like unobtrusive measures than standard paper assignments for tapping into perspectives and judgements and, therefore, are less likely to reflect the bias toward socially acceptable and official views, including those of the instructors in a classroom (Webb et al. 1966).

In addition to encouraging students to reveal their judgements, we wanted them to reflect upon them as well. Perspective-taking, or seeing one's judgement in relationship to others, is important for gaining critical self-reflection. We offered competing perspectives of events routinely in the classroom, giving significant attention to the police views versus the citizen's view, and to competing views among police and among citizens, always focusing on story accounts of specific events (e.g., police use of deadly force as reported by the media, as told by a police officer). The goal was to engage the students in the process of "cognitive empathy" or having them work towards a capability to both identify another perspective and to put themselves in "the other person's shoes." This is consistent with game theorists findings that using this heuristic tool reduces aggressive confrontations among individuals and groups (Jencks 1990); and is recognized as essential to the mediation of conflict (Fisher and Ury 1991). The narrativebased assignment was a test of students' ability to engage in perspectivetaking. 
Perspective-taking is important for contemporary policing as a shift is made away from the professional model of policing, and the distance it created between the police and neighborhood residents, to community policing (Skolnick and Bayley 1988). Community policing acknowledges that the police are limited in their abilities to control crime. Police are encouraged to expand the police function beyond crime control to include reducing fear of crime, solving problems, increasing order, increasing citizen satisfaction, and improving the quality of life (Bayley 1994; Greene and Mastrofski 1988; Rosenbaum 1994). Officers also are encouraged to develop innovative ways to respond to problems, and law enforcement becomes only one tool that is available to them. Community policing also requires officers to rely on neighborhood residents to provide information, to provide organizational legitimacy and to serve as a form of informal social control in their neighborhoods.

The reliance of police on community residents requires greater interaction with community residents who may hold different perspectives than the officers. As a result, a shift to community policing requires more than an expansion of the police function and of the tools police use to respond to situations. Community policing also requires a change in the characteristics of individuals who become officers. Community police officers need to be able to engage in perspective-taking. For contemporary police officers to engage in effective interaction, they need to have ". . . a capacity to envision the work through the eyes of another, to develop a broader perspective, and to hone evaluative and communicative skills" (Skolnick and Bayley 1988:19). This narrative-based writing assignment helped students engage in perspective-taking to develop these skills.

\section{THE NARRATIVE-BASED WRITING ASSIGNMENT}

The narrative-based writing assignment was designed to help students engage in perspective-taking and evaluation to make an informed judgement about the police decision-making that occurred in the events they described. The writing assignment involved three distinct components. Students were initially asked to write a story describing the experience of an urban resident or group and the police. The story could be drawn from personal experience or from events reported in the media. The elements of a story were reviewed to help students develop a complete perspective of the events that took place. Students were instructed to provide a factual and detailed description of the events that included what happened, where the events took place and who was involved. Emphasis was placed on including as much detail as possible. Students were expected to describe the race, gender and age of the residents involved in the encounter, and of the police officers as well. In addition, we drew their attention to the significance of place or where the encounter took place, asking them to include 
descriptions of the neighborhoods, roadways and/or commercial establishments relevant to the events. They were expected to describe the social identities of the characters and the territory or place where the events transpired because the readings (particularly Anderson 1990; Herbert 1998) and classroom presentations emphasized the significance of those factors in shaping the practical reasoning of the police.

After developing a story from a single perspective, students were asked to identify a competing perspective of the action-events that took place within the story. In identifying a competing perspective, students were asked to obtain the perspective of another source. If they told a story about a personal experience with the police, they were asked to seek the perspective of a police officer. Students were told they could not create a competing perspective based on their own perceptions of how another individual may have interpreted the same events. Identifying the perspective of another source was also not enough to create a competing perspective. Perspectives coming from different sources can still be in agreement about what transpired. To qualify as a competing perspective, there needed to be different views about the actions taken by police within the story. Something about the events, the people involved, and/or the place of the encounter needed to be contested.

After developing the story and its competing perspective, students were asked to turn in the first two sections of the narrative-based writing assignment. This allowed us to review their stories to ensure they had identified an event involving a police-citizen encounter and to ensure they had provided a sufficient level of detail. It also allowed us to assess their understanding of competing perspectives and to be sure they had identified a competing perspective of the events that took place. Grades were not assigned to the papers at this time. Students did receive feedback that would allow them to improve the first two sections of the paper before a grade was assigned. The final component of the paper asked students to assess the competing perspectives and make a reasoned judgement about the police decision-making that took place. Students focused their evaluations by devising an evaluative question that identified a key policing issue within their narrative. Students then developed a response to their question using norms and analytical constructs discussed in class and through the use of other academic sources.

\section{ACCOMPLISHING THE ASSIGNMENT}

For this assignment, students developed stories, identified competing perspectives and engaged in evaluation of those perspectives. In this section, we discuss how the assignment was accomplished, giving particular attention to how we focused the students on storytelling, guided them to develop competing perspectives of policing, and encouraged them to evaluate the perspectives so that they could derive grounded judgement about 
the right thing to do. In presenting the prescriptive pedagogy, we make references to student papers to show how students treated the competing perspectives and evaluative phases of the assignment.

\section{Focusing on Stories}

Laying the groundwork for the narrative-based writing assignment began with the first class meeting. In the first class meeting of the semester, we provided the students with a series of newspaper stories, revolving around an unresolved local controversy related to policing. One such controversy involved a group of municipal police officers who fatally shot a Hispanic teenager holding a butcher knife. The police came into contact with the teenager after the parents called for help to calm their son who had apparently been drinking alcohol. It was a high profile incident reported in the local newspaper over many months. The articles gave detailed accounts of the settings in which the incident took place, featured those directly involved in the incident as well as individuals and groups who weighed in on the events over time. Over time, media coverage introduced a number of plots or story lines ranging from what actually transpired at the time of the shooting to reflections over tensions between the police and the Hispanic and African American communities in the municipality.

We drew upon this packet of articles throughout the first several weeks of the class, using the material initially to get students, most who were social science rather than humanities oriented, to think in terms of stories, particularly about three elements of a story - characters, setting and plot. Teaching them how to take a story apart in the classroom gave them the essential knowledge they needed to be able to create stories on their own as the assignment required.

At the same time, each element of the story related to a dynamic in human decision-making that we featured in the readings and class presentations throughout the term. People, including police officers, decide what to do based, in part, on who they are dealing with and, therefore, we used the story element of characters to introduce them to the significance of social identities and processes of identification (Oberweis and Musheno 1999; Shearing and Ericson 1991). Also, human decision-making is contingent on where events transpire or the territory in which events are played out (Herbert 1997). Introducing them to the setting of a story provided a way to begin talking about the significance of space, place and territory to police decision-making. Finally, decision-making is undergirded by beliefs or culturally-embedded norms. Focusing initially on plot, particularly what normative guidance a story is offering, enabled us to begin introducing students to the range of norms that researchers claim are at work when police exercise or withhold their coercive powers (Herbert 1997). By having the students work with these stories, we were able to have them gain 
the basic skills they needed to carry out the assignment while they "discovered" the key concepts we would introduce later through readings and classroom presentations.

\section{Competing Perspectives}

The entire course is designed around competing perspectives. At the most fundamental level, it introduces urban policing from the perspective of doing police work, and from that of being policed. One of the basic sections of the course focuses on how the police situate themselves in relation to urban territory and citizens, and explores the dilemmas, contradictions, and paradoxes of urban policing. It includes attention to the perspectives of line officers versus police managers as well as different groups of line officers (e.g., male vs. female officers). Another basic section is devoted to being policed as urban subjects. It takes up perspectives of citizens who are under the gaze of the police (e.g., urban youths of color) while investigating points of difference among urban residents (e.g., block watches, gang members who are watched) and across urban territory (e.g., business districts, gentrified neighborhoods, barrios ).

In addition to readings and classroom presentations, we invite guest speakers who have divergent positions regarding an unresolved, current policing controversy high on the local public agenda. Students receive packets of news stories that focus on the same issue. As indicated above, in one semester we focused on the fatal shooting of a Hispanic adolescent by a group of police officers. As students read about the issue in class during the first days of the semester, they are asked to identify competing perspectives about the events surrounding the shooting, to mark contrasting representations of the youth who was killed and the police who used lethal force, and to describe the accumulation of support for different parties to the incident as a way to introduce them to issues of power. We form small groups among the students, asking each group to represent a different party to the controversy, and invite them to play out their perspectives in class.

The writing assignment is presented as another way for students to learn about competing perspectives. Their stories must be told from the perspective of a real or imagined party to a controversy. Moreover, each student is required to seek the perspective of someone else, either by asking a person who they think will react differently to their story, or by identifying someone in a reported story that stands in opposition to the perspective of their teller of the story. The following excerpts illustrate the different ways students responded to this phase of the assignment.

In one story a student told of a situation where he was given a break by the officer who pulled him over. While he may have received a careersaving break, his friend provided a different perspective of the events that took place: 
As John's friend, I am glad he was not arrested. I understand that the consequences of such a conviction (for DUI) might prevent John from getting a job as a police officer. On the other hand, as someone who was watching the whole incident I realize how the system was circumnavigated by the officer. . .

The officer gave John a break because John was white like the officer. For the sake of an argument, let's say John was an African American male driving a much older car that needed repairs and painting desperately. Let's also put John in some saggy pants and dreadlocks. Under these circumstances there is no doubt that John would have been taken in and booked on DUI charges. . .

Because of incidents like this, minorities raise valid points when they criticize the police and how they treat and arrest members of the community with different racial backgrounds. The only way for the police department to change this perception is for them to apply the law fairly to all citizens. By letting some offenders go and arresting others, the credibility of the law enforcement community is brought into question.

Students recognized competing perspectives both between groups and within groups. A student who wrote about the sweeps of illegal immigrants by a municipal police department highlighted this point:

This round up was the source of tremendous controversy for many people both in and outside of the community. Police claim to be doing what the community needs and being 'beaten up' about doing their job. Business owners claim this is the fastest way to deter business, and eventually run these Hispanic businesses out of the area. Other community activists claim that police were discriminatory in their actions and singled out only Hispanic looking people and people who spoke Spanish. Still other members of the community cheer the police in their effort to protect their neighborhood.

When talking in more detail about the "community perspective" it was stated that "Even within the community there are several perspectives." The same observation was made when looking at the "government perspective." "Local officials are not in any more agreement than the residents."

The competing perspectives identified above illustrate the student's recognition that a competing perspective does not only come from another source, it also provides a different view about the events that took place and the decisions that were made.

\section{Raising Evaluative Questions}

The final phase of the writing assignment asks each student to identify a fundamental issue of police decision-making that is at the core of the story they constructed and use social scientific reasoning to assess that issue. They were expected to conclude with an evaluative question, or a question that, when answered, renders an informed judgement about the appropriateness of police decision-making illustrated by the story. In our 
experiences as teachers, we have been concerned about how quickly students are willing to render an opinion about police action and how often these opinions simply embrace popular pro-police or anti-police ideology.

Rather than asking the students to offer opinions, this phase of the assignment pushes them to assess the issues first, and then derive questions that address what is at stake normatively in determining the right thing to do. By asking them to assess and take a step in the direction of reasoning about the right thing to do, we intended to avoid the temptation for instructors to do all the assessments and evaluations of police decision-making for the students.

Throughout the semester, we offered students tools for assessing police decision-making, focusing mostly on the significance of social identities and of territoriality, as described above. We introduced the students to the significance of these factors to police decision-making first by having them read and discuss the Story of Francisco (see Appendix A). When we addressed these dimensions later through readings and class presentations, we returned to this story and others to provide them with tangible examples of how identities and territory are highlighted in police stories about working the streets.

We relied significantly on the Story of Francisco because it reveals competing, indeed conflicting, perspectives among police officers over how to handle an incident, and it offers rich exposure to the significance of identity and territoriality to police decision-making. In addition, we drew on this story because the point of view articulated by the officer, as storyteller, is unsettling in that he does not invoke his legal authority in a situation where he clearly could have done so. Indeed, as we anticipated, many students react initially to the story by condemning the officer for his failure to "follow the law."

The story focuses on a working-class Hispanic man, Francisco, who is also a small-time marijuana dealer. Two of Francisco's affiliates came to his house to rob and kill him. Francisco was able to grab an assailant's gun and fire shots at both of them, including discharging a number of rounds outside as they fled the scene. The Hispanic officer telling the story felt that "Francisco had been through enough. . . . He was defending himself. Period." The officer invokes the significance of space and territory, giving great weight to the attack on Francisco taking place in his home while realizing that Francisco crossed the line when he continued to fire at the assailants outside his home as they fled. Also, the story is rich with references to the identity and character of Francisco, and the identity of the supervisors who wanted Francisco arrested. The story reveals how the officer telling the story positions himself in relationship to the identities of Francisco and the supervising officers who ordered his arrest. It invokes at least three norms that weigh on the officer's decision about what he should do, specifically law, bureaucratic control, and morality (Herbert 1997). 
The Story of Francisco is also a valuable heuristic tool because it stimulates students to render instant opinions of the officer's judgement and related action while enabling the instructors to turn the students in the direction of asking analytical and evaluative questions about police decision-making. Initially, we ask them to consider incident-specific questions - why did the officer decide not to arrest Francisco, did he make the right or wrong decision and why? These specific questions led, with time and exposure to readings and classroom presentations, to broader questions about what factors influence police decision-making and when, if at all, police should make exceptions. We treated the writing assignment as a capstone experience for the students to demonstrate their ability to analyze police decision-making and engage in evaluative reasoning about police actions.

Many of the papers related to a central dilemma in policing: how can the police maintain order in a way that treats people fairly? This dilemma was highlighted by students who evaluated a sweep of illegal immigrants conducted by a municipal police department in cooperation with the United States Border Patrol. The following excerpt describes how the dilemma was posed by one student:

The American public is convinced that illegal immigration is a problem, as is the government that represents that public. That same citizenry is also extremely concerned with protecting its civil rights. This creates an obvious dilemma: How can law enforcement officials, both on a local and federal level, protect American citizens' civil rights while concurrently enforcing immigration laws?

Her evaluation of this question led her to recognize that both the desired outcome and the way it will be achieved need to be considered. While she did not believe that the Fourteenth Amendment had been violated, and she agreed with the pursuit of illegal immigration by law enforcement personnel, she did raise questions about how they tried to achieve the desired outcome:

I would disagree that the sweep was the most effective way in which to control illegal Mexican immigration. I do not know that there is one method that everyone would be in agreement on, but I do think that more community involvement in developing procedures for this control is vital. . Perhaps some dialogue between Mexican-Americans, INS and local police officials would be a good place to start in determining the best method of controlling immigration.

Other students raised process-oriented questions about what factors police use to guide their decisions in encounters with residents. One factor that was frequently discussed was the issue of race. One student believed he may have benefited from having a background similar to that of the officer who stopped him, which resulted in him not being charged with DUI. 
To this day I appreciate what the officer did for me. . .In retrospect, I can only conclude that the officer looked at me and did color coding. He saw me as a white male, in a late model car as no threat to the community. In addition, as a former criminal justice major too, he saw me as someone like him and therefore I was no danger to him or the community.

While as an individual the outcome was favorable, it also raised a question for this student about ". . how race affects a police officer as he/she carries out the duties of their job. . .How does race affect policing strategies? How are people of color treated differently by the police?"

To answer this question, the student sought evidence that would indicate how minorities may be treated differently. In doing so he discovered that some forms of data on this issue are not available. For example, “. . police officers do not keep track of the offenders who they let go." What he did find is that minorities make up a disproportionate number of those arrested and there are different explanations for why this may occur. He also found that there was anecdotal evidence that described how minorities are often treated by the police. As he assessed the various forms of evidence he reached the conclusion that ". . police officers use race as a method to categorize possible suspects. . .I realize now how lucky I was the night I was stopped. I also realize how frustrating it must be for minority men to be stopped by police officers just for the color of their skin."

\section{EVIDENCE OF STUDENT GROWTH}

While students are often motivated to complete class assignments for pragmatic reasons, instructors maintain the hope that their courses will play a role in student development. Our hope was that we would be able to improve our students' abilities to make reasoned judgements by drawing on social science knowledge, and applying norms and principles of justice to multiple and competing perspectives of encounters between urban residents and the police. We wanted our students to recognize the difference between their opinion and a grounded perspective.

After reading our students' papers, we saw signs of student learning, although the learning that took place varied from student to student. One area where learning took place was in acquiring competing perspectives. When the stories and competing perspectives were initially reviewed, it was apparent that some students did not understand the idea of a competing perspective. Some students creatively wrote the competing perspective in the first person, often as though they were telling the story from the officer's point of view. In a number of instances these perspectives were based on the individual's perception of what was going through the officer's mind. These perspectives generally did not raise questions about the outcome of the events or the decision that was made, but provided a rationalization for the outcome. After receiving feedback about the stories and 
competing perspectives, students were able to share their stories with another source to develop a competing perspective that raised questions about the events that took place.

In addition to being able to recognize competing perspectives, students displayed an ability to engage in perspective-taking. In the evaluative component of some papers, it was clear that students placed themselves in "the other person's shoes." One illustration of this can be seen in the story of the student who was not charged with DUI. Through the course of his evaluation, he made a distinction between an outcome that was favorable to him as an individual and an outcome that was fair. While he benefitted from the officer's behavior, he realized the officer's response may not be the most appropriate way to engage in policing; a lesson he may be able to use on the streets as an officer. The fact that this student was able to reach a conclusion that he should have been charged with DUI, an outcome that was not favorable to him, illustrates that he engaged in perspective-taking. He thought about how others in similar situations with different backgrounds would fare in the same situation, and how others would perceive how he was treated by the officer.

The stories and their evaluations also helped students develop their position with regard to certain police issues. These positions were revealed to us through their writing. When the writing was coupled with their participation in class discussions, we were able to see if there were consistencies or contradictions in their belief systems.

Through class discussions, one student revealed a belief that, if an individual engages in behavior that is disrespectful to a police officer, there should be an expectation of an aggressive police response. He then told a story where his friends engaged in disrespectful behavior by trying to run from the police and they experienced an aggressive, multi-agency police response. While the student could have felt an affinity for his friends and perceived the police response as unjust, his conclusion was based on academic research and revealed a consistency to his beliefs.

In conclusion, I feel (none of the departments involved) did any injustice to my friends. All of the departments followed the rules of police pursuit and protected the public at the same time.

In another instance, an inconsistency was revealed. Early class discussions about what factors guide police decision-making revealed a number of students who believed strongly that the police are and should be guided by law. In discussing The Story of Francisco, these students believed the officer acted inappropriately by not filing charges against Francisco. However, the stories told by these same students of their own encounters with police revealed incidents where they had broken a law and been treated leniently at the officer's discretion. They all looked upon this action by the 
officers in a favorable manner. Bringing these consistencies and inconsistencies to the attention of students seemed to help as they learn to make reasoned judgements.

Finally, students displayed learning by intimating changes in their belief systems based on new information they acquired. While the students identified above showed an inconsistency in their beliefs, they also showed learning. As they made their evaluations, they recognized that discretion is an important part of police work, and that factors other than the law guide police decision-making.

The most difficult aspect of the writing assignment for students was engaging in evaluation. Some students were able to successfully evaluate their stories and competing perspectives, and some students stopped short of making a judgement about whether the police made the appropriate decision. Helping students achieve this aspect of the writing assignment is an area that deserves further attention.

Our experience with the narrative-based writing assignment has been very positive, and we have some evidence to suggest it has value; however, there are other ways we could look at whether the assignment was effective and impacted student learning beyond the immediate context of the writing assignment. We suggest two ways to help us identify what learning has taken place that are also tools to help increase student learning.

The first involves The Story of Francisco. When the story is first introduced to students they could be asked to analyze and evaluate the officer's actions in writing. At the end of the semester the story can be revisited and a new response written. The two responses can be compared to identify whether and how the narrative-based writing assignment and the tools they acquired to do it influenced their assessment and evaluation of this story.

A second strategy is to have students share their stories and competing perspectives with others in the class and have students engage in an evaluation of another student's story. This would allow multiple comparisons to be made that could also enhance student learning. Students would have an opportunity to see how someone else assessed police decision-making in their story. Students could also compare the evaluation they made about their story with their evaluation of another situation to see how they are similar and how they are different.

Overall, the use of the narrative-based writing assignment allowed us to engage our students in ways that differ from a traditional college writing assignment. This occurred in part because of the integration of the writing assignment with the class readings, presentations and discussions. As a result, the use of stories of police-citizen encounters and competing perspectives helped students to reflect on their own beliefs about appropriate police decision-making. It also reshapes our role as instructors to one where we facilitate student growth and decision-making processes rather than dictating them. 


\section{REFERENCES}

Anderson, E. 1990. StreetWise: Race, Class and Change in an Urban Community. Chicago: University of Chicago Press.

Argyris, C. and D. A. Schon. 1978. Organizational Learning: A Theory of Action Perspective. Reading, MA: Addison-Wesley.

Bayley, D. H. 1994. Police for the Future. New York: Oxford University Press.

Dryzek, J. S. 1990. Discursive Democracy. Cambridge: Cambridge University Press.

Ewick, P. and S. Silbey. 1998. The Common Place of Law: Stories from Everyday Life. Chicago: University of Chicago Press.

Fisher, R. and N. Ury. 1991. Getting to Yes, Second Edition. New York: Penguin.

Giroux, H. A. 1996. Fugitive Cultures: Race, Violence and Youth. New York: Routledge.

Gooding-Williams, R. (ed.). 1993. Reading Rodney King, Reading Urban Uprising. New York: Routledge.

Greene, J. R. and S. D. Mastrofski (eds.). 1988. Community Policing: Rhetoric or Reality? New York: Praeger.

Herbert, S. 1997. Policing Space: Territoriality and the Los Angeles Police Department. Minneapolis, MN: University of Minnesota Press.

Hummel, R. 1990. "Uncovering Validity Criteria for Stories Managers Hear and Tell." American Review of Public Administration 20(4):601-22.

Hummel, R. 1991. "Stories Managers Tell: Why they are Valid as Science." Public Administration Review 51(1):31-41.

Jencks, C. 1990. "Varieties of Altruism." In J. Mansbridge (ed.), Beyond Self Interest. Chicago: University of Chicago Press.

Lipsky, M. 1980. Street-Level Bureaucracy: Dilemmas of the Individual in Public Services. New York: Russell Sage Foundation.

Martin, J. 1982. "Stories and Scripts in Organizational Settings." In A. H. Hastorf and A. M. Isen (eds.), Cognitive Social Psychology, pp. 255-305. New York: Elsevier Science Publishers.

Musheno, M. 1986. "The Justice Motive in the Social Police Process: Searching for Normative Rules of Distribution." Policy Studies Review 5(4): 697-704.

Oberweis, T. and M. Musheno. 1999. "Police Decision-Making: The Constitution of Citizens." Law and Social Inquiry 24(4): 897-923.

Pettigrew, A. M. 1979. “On Studying Organizational Cultures." Administrative Science Quarterly, 24(4): 570-581.

Polkinghorne, D. E. 1988. Narrative Knowing and the Human Services. Albany, NY: State University of New York Press.

Rosenbaum, D. (ed.). 1994. The Challenge of Community Policing: Testing the Promises. Thousand Oaks, CA: Sage Publications.

Schank, R. C. 1990. Tell Me a Story: A New Look at Real and Artificial Memory. New York: Charles Scribner's Sons.

Schneider, A. and H. Ingram. 1997. Policy Design for Democracy. Lawrence, KS: University of Kansas Press.

Shearing, C. and R. Ericson. 1991. "Culture as Figurative Action." British Journal of Criminology $42(4)$ : 481-506.

Skolnick, J., and D. Bayley. 1988. "Theme and Variation in Community Policing." In M. Tonry and N. Morris (eds.), Crime and Justice: A Review of Research, Volume 10, pp. 1-37. Chicago: University of Chicago Press.

Tyler, T. R. 1990. Why People Obey the Law. New Haven: Yale University Press.

Tyler, T. R., R. Boeckmann, H. Smith, and Y. Huo. 1997. Social Justice in a Diverse Society. Boulder, CO: Westview Press.

Webb, E. J., D. T. Campbell, R. D. Schwarts, and L. Sechrest. 1966. Unobtrusive Measures. Skokie, IL: Rand McNally. 


\section{APPENDIX THE STORY OF FRANCISCO}

This incident occurred a couple of years ago. There was an individual that had been involved in a lot of criminal activity including shootings and his name was Steve. Steve never really seemed to be able to do anything that was above the board. He never seemed to have a job. When he did have a job, he would steal from the employer. What he eventually started doing was dealing small amounts of marijuana. He had a cousin by the name of Cory. Cory is a black male. Steve is a mulatto. Well, Steve and Cory met with another individual who was a Mexican guy. He (the Mexican guy) had a wife and she was white. He had been a laborer his whole life. When I talked to Francisco he had chemical burns on his arms and back and he explained to me that one time he had lived in a rural area and had to carry this chemical container on his back to spray weeds in these huge fields and it was a difficult life. He came from a migrant worker's family in Texas and he came to Big City and settled down. He had a wife and a baby and wasn't able to make ends meet. So he started dealing small amounts of marijuana, which is, of course, against the law.

He started dealing with Steve and he thought that Steve was his friend. Steve was selling small amounts of marijuana for him, and one day Steve and his cousin Cory decided that they were going to rip Francisco off. So they drove over to Francisco's house. It was a duplex in a residential area. It was a nice little neighborhood. I wouldn't have expected the problems to have occurred in that neighborhood. Cory went into the residence. Steve had called Francisco ahead of time and told him, "We're gonna come over. My cousin is coming over with me. We're going to talk to you for a little bit."

He confronted Francisco, took a hat Francisco had and marched him through the house gathering up a bunch of valuables. Francisco's wife was at work. She was a waitress. So he put the gun to Francisco's head. He took him back out to the living room and, while holding Francisco at gunpoint, he started closing the blinds in the living room and he ordered Francisco down on his knees. Francisco knew then that he was going to be executed. Francisco was about 5 ' 8 " and weighed about 220 or 250 pounds. He was a stout little guy. Cory weighed about 130 and he was about 5'8". Francisco later told me - I got to interview him - that he got to looking at Cory and realized that he was much stronger. And when he had the opportunity, he grabbed the gun with both hands and forced it up and got Cory off his feet and he started swinging him from side-to-side across the room. And he threw him into a kitchen table and collapsed the table. And it was enough to make Cory release his hold on the gun.

$\mathrm{He}$ - Cory - then ran and we were never able to tell if he ran through the Arcadia door or if bullets preceded him, but his, suddenly his high- 
capacity was being used on him. Well, he took a couple of rounds through the midsection, but he kept on running. Francisco was right behind him and Francisco fired at him across the parking lot and Cory ran to where Steve was waiting to drive getaway. Francisco shot through the back of the car. One bullet went through the gas tank and another one went through the trunk and into the driver's seat and stopped just short of Steve's back. They left at a high rate of speed, bounced out onto the roadway, fortunately there were no cars coming, and Francisco continued to shoot this highcapacity $9 \mathrm{~mm}$. The gun had about a 16 round capacity. And some of the bullets went directly across the roadway and hit a house across the way.

They fled to the hospital and so we started to receive phone calls at the police department about a residential burglary that had taken place and then there was a shooting victim at the hospital. I was a detective at the time. A couple of detectives went to the hospital and started looking around and listening to the story and I went to the scene and was given the story from Francisco. What the detectives at the hospital found was that they had stolen guns in the car and they had taken the money and stashed it in some bushes outside the car outside the emergency room. Well, of course, supervisors came to the scene and they said, "OK, we're going to arrest the driver of the car. We're going to file charges on the wounded suspect."

At the same time, Francisco, who was traumatized and upset said, "Yup, I do deal with small amounts of marijuana. I'm scared. He was gonna kill me; I was afraid for my life. The supervisors decided to arrest him for endangerment for shooting the gun and having it cross the roadway. What I would have preferred was to file charges on Francisco or let the entire package, the entire case, be reviewed by the county attorney, which eventually almost always happens. Every case is sent to the county attorney's office and they decide what to file on people. Very often, we can file a case against a particular person, a request, and they'll turn it down. Or sometimes they'll read a report and say, "We need to file on this person." The supervisors were adamant that Francisco be arrested. I didn't care for that idea. I think to them, Francisco was seen as a semi-literate Hispanic. These were white supervisors making the decision. Francisco had just gone through a life-threatening situation. He had had enough. Francisco had come clean with us. He said, "Yup, I'm a small-time marijuana dealer." He was terrified and traumatized. His wife came home and she was upset that we were going to take him to jail.

Ultimately, what happened was I didn't file a case on him. The other two went to prison and I didn't file anything else. I thought, personally, that Francisco had been through enough. Francisco had been traumatized, upset, he was fearful for his life and he was just defending himself. Period. He had every right to shoot. We all understood that his shooting to kill Cory was completely justified. They were upset because a couple of rounds 
went across the roadway and struck another house. Well, I'm sure he had tunnel vision. He wasn't thinking about that. He was defending himself. His life had been threatened and the discretion I used was that I didn't file a case on him. He was afraid for his life. I don't know what Francisco's doing today. I've never seen him again, don't want to, but my feeling then was that he'd suffered enough.

You know what? Francisco had been terribly betrayed. When I was talking with him, he couldn't believe it. He kept saying, "He's been in my home before. He's had dinner with me. I've loaned him money. I've looked after him." I think that an invitation into his home means something important in Francisco's culture. He was taking care of Steve. Because Steve just kind of wandered. No one could control Steve. His mother, really, while she would defend him when he was in trouble there were really a lot of problems between them. Francisco was furious. When I asked him, "What would you do to him, if you could?" He said the way a Mexican kills someone, a Mexican way of torturing is that he would stake him out on a sheet of plywood and he'd slit him with a razor blade or knife down both sides of his back alongside the ribcage and then fill it with salt. And listen to him scream. He was angry and he was upset. I mean, that's a terrible thing to say, but he was trying to tell me this and he was also terribly relieved that his wife wasn't there. He was saying, "I know that if my wife had been there, he would have raped her." And he probably would have. These are just the kind of people you run into sometimes. You just know that if they're there, they're gonna cause trouble.

Francisco wasn't a bad guy. He'd been arrested one other time for burglary in a small community here in this state. He was around high school age. He and his friends burglarized a rancher's house and as he was coming home he passed them on the highway. He sees them with all their stuff. He bellied up, said he did it. Before this incident, he hadn't been in town very long. He'd grown up in Texas and then in a little community in the southwestern part of the state, here. Francisco was just doing the best he could. These were terrible burdens he had on his back, for a 28 year old guy. He also had his little sister living with him. She was still in high school. I'm not sure where the parents were, but he was raising his little sister. He had a little brother living with him and his brother was in high school. He had a little family situation set up there and he was trying to make ends meet. I've seen people that have worked hard during their lifetimes, like Francisco had.

Steve, on the other hand, deserves trouble. He had been involved in other shootings. Steve had told another homicide detective before that he was untouchable because his family was judicial. What that meant was that, well, first of all, his stepfather was at one time a Big City police officer. We never were able to determine what the story was with the stepfather. The mother was extremely hostile. She was the personal secretary for a superior court judge here. So Steve's viewpoint was that he was untouchable. 
HeinOnline -- 11 J. Crim. Just. Educ. 1662000 